\title{
PENGARUH PEMBERIAN INFORMASI DAN TRANSAKSI ELEKTRONIK TERHADAP PENGETAHUAN MASYARAKAT DELI SERDANG
}

\author{
Syahrul Bakti Harahap ${ }^{1)}$, Enny Fitriani ${ }^{2)}$ \\ Universitas Muslim Nusantara Al Washliyah ${ }^{1,2)}$ \\ e-mail : syahrulbakti71@yahoo.com
}

\begin{abstract}
ABSTRAK
Pendidikan tentang kesadaran hukum hendaknya diberikan secara formal di sekolah maupun non formal di luar sekolah bagi masyarakat luas. Harus ditanamkan kepada masyarakat bagaimana menjadi warganegara yang sadar akan hukum, sehingga masyarakat mengetahui hak dan kewajibannya sebagai warganegara Indonesia yang baik.Seiring dengan perkembangan tehnologi komunikasi sering masyarakat terjerat dengan hukum akibat ketidak tauan tentang undang-undang No. 19 tahun 2016 tentang informasi dan transaksi elektronik (ITE). Pengabdian kepada masyarakat ini dilakukan di Desa Afnawi Kecamatan Sunggal Kabupaten Deli Serdang. Mitra pada kegiatan ini adalah Ibu-Ibu Anggota perwiritan, masyarakat sekitar yang berpartipasi mengikuti kegiatan pengabdian kepada masyarakat yang dilaksanakan oleh dosen / staf pengajar serta melibatkan mahasiswa/i Universitas Muslim Nusantara Al Washliyah. Pelaksanaan kegiatan ini berupa sosialisasi, penyuluhan dengan memberikan pengetahuan tentang hukum, perundang-undangan, sanksi hukum dan penerapannya serta melakukan diskusi interaktif dan juga konsultasi hukum, yang nantinya dapat membuka pemahaman masyarakat akan sadar hukum.
\end{abstract}

Kata kunci: sosialisasi,sadar hukum,penerapan sanksi

\begin{abstract}
Education about legal awareness should be given formally in schools and non-formal outside schools for the wider community, must be embedded in the community how to become law-conscious citizens so that the community knows their rights and obligations as Indonesian citizens. Along with the development of technology, people are often entangled in the law due to an understanding of Law Number 19 Year 2016 concerning Information and electronic transactions. This community service was carried out in the village of Afnawi, Sunggal District, Deli Serdang Regency. The partner in this service is the mother-in-law of the company and the surrounding community who participated in this service. conducted by Muslim University Al Wasliyah. The implementation of this activity is in the form of socialization of legal witness legislation, and its implementation as well as conducting intractive disscussions and also legal consultations. which can open up public understanding of Law Number: 19 Year 2106 concerning Information and Electronic Transactions.
\end{abstract}

Keywords : socialization, law conscious, application of sanctions 


\section{PENDAHULUAN}

Pendidikan tentang kesadaran hukum hendaknya diberikan secara formal di sekolah-sekolah maupun non formal di luar sekolah bagi masyarakat luas. Harus ditanamkan kepada masyarakat bagaimana menjadi warganegara yang sadar akan hukum, sehingga masyarakat mengetahui hak dan kewajibannya sebagai warganegara Indonesia yang baik.

Setiap warganegara berkewajiban untuk mengetahui tentang hukum positif yang berlaku di Indonesia dan harus mematuhi asas legal, yang memberikan kewajiiban kepada masyarakat luas untuk memahami dan mematuhi tentang peraturan-peraturan perundang-undangan yang berlaku. Undang-undang apabila telah diundangkan berdasarakan asas fiksi hukum, bahwa warganegara tidak bisa beralasan bahwa hukum tersebut tidak dimengerti dan tidak dipahaminya.

\section{Setelah}

masyarakat

memehami tentang isi undangundang maka masyarakat akan menyadari manfaatnya selanjutnya akan mematuhinya. Menimbulkan kesadaran bahwa didalam pergaulan hidup seharai-hari ditengah-tengah masyarakat tidak boleh melanggar hukum, harus menghormati hak orang lain, agar berusaha tidak merugikan oranglain. Hal inilah yang ditujukan timbulnya kesadaran hukum bagi masyarakat.Sehingga tercipta kerukunan antar masyarakat.

Berdasarkan Undang-undang

No. 11 tahun 2008, yang dimuat dalam konsideran pada huruf, $b$, menyebutkan bahwa globalisasi informasi telah menempatkan Indonesia sebagai bagian dari masyarakat dunia sehingga diharuskan membuat aturan mengeneai pengelilaan dan informasi elektronik di tingkat nasional sehingga pembangunan tehnologi informasi dapat dilakukan secara optimal, merata dan menyebar keseluruh lapisan masyarakatguna mencerdaskan kehidupan bangsa.

Berdasarkan Pasal 1 Ayat (1) undang-undang N0. 19 Tahun 2016 jo Undang-undang No. 11 Tahun 2008, tentang informasi dan teransaksi elektronik yaitu, Informasi eloktronik adalah satu atau sekumpulan data elektronik, termasuk tetapi tidak terbatas pada tulisan suara, gambar, peta, rancangan, foto, elektronik dan interchange (EDI), surat elektronik (elektronik mail) telegram, teleka, telecopy, atau sejenisnya, hurup, tanda, angkakode akses, symbol atau porporasi yang telah diolah yang memiliki arti atau dapat dipahami oleh orang yang mampu memehaminya.

$$
\text { Pasal } 1 \text { Ayat (2) undang- }
$$
undang No. 19 Tahun 2016, menyebutkan transaksi elektronik adalah perbuatan hukum yang dilakukan menggunakan komputer jaringan komputer dan/atau media elektronik lainnya.

Akibat ketidak tahuan masyarakat terkadang masyarakat tidak sadar dengan perbuatan yang dilakukannya dalam menggunakan sosial mendia berakibat hukum.Pasal 45 Ayat (1), menyebutkan, setiap oarang yang dengan sengaja dan tanpa hakmendistribusikan dan/atau mentransmisikan dan/atau dokumen elektronik yang memiliki muatan yang melanggar kesusilaan sebagaimana dimaksud dalam Pasal 27 Ayat (1), dipidana dengan pidana penjara paling lama enam tahun 
dan/atau denda paling banyak Rp.1.000.000.000. (satu miliar rupiah).

Pasal 45 Ayat (2), setiap orang yang dengan sengaja tanpa hak mendistribusikan dan mentransmisikan dan atau membuat dapat diaksesnya informasi elektronik dan/atau dokumen elektronik yang muatan perjudian sebagaimana dimaksud dalam Pasal 27 Ayat (2), dipidana dengan penjara paling lama 6 tahun, dan atau denda paling banyak Rp.1.000.000.000. (satu miliar rupiah).

Pasal 45 Ayat (3), setiap orang dengan sengaja dan tanpa hak mendistribusikan atau mentransmisikan dan/atau membuat membuat dapat diaksesnya informasi elektronik dan/atau dokumen elektronik yang memiliki muatan muatan penghinaan dan atau pencemaran nama baik sebagai mana dimaksud dalam Pasal 27 ayat (3), dipidana dengan pidana penjara paling lama 4 tahun dan/atau denda paling banyak Rp.750.000.000. (tujuh ratus lima puluh juta rupiah).

$$
\text { Pasal } 45 \text { Ayat (4), Setiap }
$$

orang yang tanpa hak mendistribusikan dan/atau membuat dapat diaksesnya informasi elektronik dan/atau dokumen elektronik yang memiliki muatan pemerasan dan/atau pengancaman sebagaimana dimaksud dalam Pasal 27 Ayat (4)dipidana penjara paling lama 6 tahun dan/atau denda paling banyak Rp.1.000.000.000. (satu miliar rupiah).

Berdasrkan Pasal 45A, Ayat (1), menyebutkan setiap oarang yang dengan sengaja dan tanpa hak menyebarkan berita bohonh dan menyesatkan yang mengakibatkan kerugian konsumen dan transaksi elektronik sebagai mana dimaksud dalam Pasal 28 Ayat (1), dipidana dengan pidana penajra paling lama 6 (enam) tahun dan/atau denda paling banyak Rp.1.000.000.000. (satu miliar rupiah).

Berdasarkan permasahan mitra maka target yang akan ditawarkan dalam kegiatan pengabdian pada masyarakat ini, memberikan penyuluhan hukum kepada masyarakatt tentang, pemberdayaan masyarakat melalui sadar hukum Informasi dan Transaksi Elektronik di Desa Kampung Lalang Kecamatan Sunggal kabuaten Deli serdang.

\section{METODE PELAKSANAAN}

Kegiatan pengabdian kepada masyarakat ini melibatkan dosen / staf pengajar dan mahasiswa/I Universitas Muslim Nusantara Al Washliyah.Adapun kegiatan pengabdian masyarakat ini, untuk menyelesaikan permasalahan mitra maka dilakukan kegiatan berupa penyuluhan hukum dengan memberikan pengetahuan tentang hukum, peraturan perundangundangan, sanksi yang diterapkan terhadap permasalahan tentang penyebaran berita bohong (Hoaks) dan serta melakukan diskusi interaktif kepada masyarakat atau konsultasi hukum.

Hasil yang dari kegiatan pengabdian kepada masyarakat ini adalah menambahnya pengetahuan mitra tentang hukum, peraturan perundang-undangan dan sanksisanksinya serta mitra dapat mencegah dan menghindari dari perbuatan yang melanggar hukum dan juga dapat memberikan informasi kepada masyarakat lainnya terhadap pengetahuan yang diperoleh selama pada kegiatan ini. 


\section{HASIL DAN PEMBAHASAN}

Target pengabdian pada masyarakat adalah kelompok masyarakat di desa Kampun Lalang Kecamatan Sunggal Kabupaten Deli Serdang yang kurang paham tentang Undang-Undang Transaksi dan Informasi Elektronik, sehingga dengan penyuluhan hukum pada masyarakat dapat meningkatkan pengetahuan tentang Pemberdayaan masyarakat melalui sadar hukum Informasi dan Transaksi Elektronik di Desa Kampung lalang Kecamatan Sunggal Kabupaten Deli Serdang.

Diaharapkan setelah memahami Undang-Undang Informasi dan transaksi elektronik Nomor : 29 tahun 2016.jo. Undangundang Nomor 11 Tahun 2008, masyarakat terhindar dari perbuatan melanggar hukum, seperti penyebaran konten kesusilaan, perjudian, penghinaan dan pencemaran nama baik dan berita bohong (Hoax).

\section{KESIMPULAN}

Bahwa

pemahaman masyarakat tentang Pemberdayaan masyarakat melalui sadar hukum Informasi dan Transaksi Elektronik di Desa Afnawi Kecamatan Sunggal Kabupaten Deli Serdang, tingkat kesadaran hukum masyarakat masih rendah tentang UU ITE. Dapat dilihat dari antusiasme masyarakat sangat tinggi untuk bertanya pada saat pengabdian ini dilakukan.

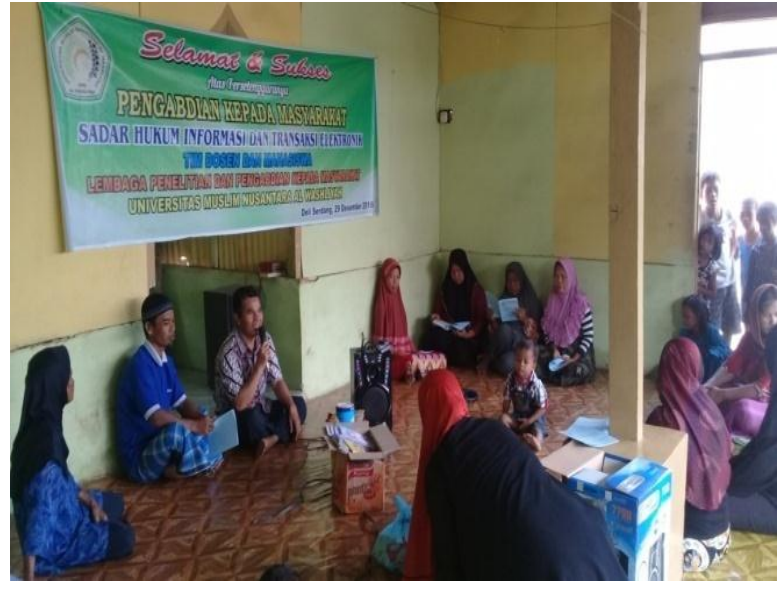

Gambar 1. Foto pelaksanaan PKM di Desa GTW Afnawi Kecamatan Sunggal Kabupaten Deli Serdang

\section{REFRENSI}

Ridwan HR, 2013, Hukum Administrasi Negara, PT. Raja Grapindo Persada, Jakarta.

Juliana Lisa FR \& Nengah Sutrisna P, 2013, Narkotika Psikatropika dan Gangguan Jiwa, Nusa Medika. Yogyakarta.

R. Soesilo, 1984, KUHP Serta Komentar-Komentarnya Pasal-demi Pasal, Politeia, Bogor.

Soekidjo Notoatmodjo, 2010, Etika dan Hukum Kesehatan, Rineka Cipta, Jakarta.

Zainuddin Ali, 2012, Sosiologi Hukum, Sinar Grafika, Palu. 